Research Article

\title{
Geochemical and Sm-Nd isotopic characteristics of metabasites from central Hainan Island, South China and their tectonic significance
}

\author{
Xian-Hua Li, ${ }^{1, *}$ Hanwen Zhou, ${ }^{1}$ Sun-Lin Chung, ${ }^{2}$ ShiJiang Ding, ${ }^{3}$ Ying Liu, ${ }^{1}$ Chi-Yu Lee, ${ }^{2}$ \\ Wenchun Ge, ${ }^{1}$ Yeming ZHANG ${ }^{4}$ AND RenJie ZHANG ${ }^{4}$ \\ ${ }^{1}$ Guangzhou Institute of Geochemistry, Chinese Academy of Sciences, Guangzhou 510640, Guangdong, China \\ (Email: lixh@gig.ac.cn), ${ }^{2}$ Department of Geosciences, National Taiwan University, Taipei 106-1\%, Taiwan, China, \\ ${ }^{3}$ Hainan Geological Survey, Haikou 570206, Hainan, China and ${ }^{4}$ Yichang Institute of Geology and Mineral \\ Resources, Yichang 443003, Hubei, China
}

\begin{abstract}
Major and trace elements and Sm-Nd isotopic data are presented for metabasites that are present as lenses within Paleozoic metasediments in the Chenxing and Bangxi regions, central Hainan Island, Southeast (SE) China. Most metabasites are metamorphosed cumulated gabbroic rocks tholeiitic in nature, and characterized by varying degrees of depletion in $\mathrm{Th}, \mathrm{Nb}$, Ta and light rare earth elements (LREE). Moreover, they show high positive $\in \mathrm{Nd}(\mathrm{T})$ values of approximately +7 , similar to those of mid-ocean ridge basalts (MORB). A Sm-Nd isochron age of $333 \pm 12 \mathrm{Ma}$ obtained for the metabasites is interpreted as their crystallization age. The combined geochemical and $\mathrm{Sm}-\mathrm{Nd}$ isotopic data suggest that the metabasites were generated by dynamic partial melting from a MORB-like mantle source in an oceanic regime. These rocks probably represent remnants of fragmented oceanic crust of the eastern part of Paleo-Tethys. They were obducted onto the continental crust as part of the 'Shilu Mélange' in earliest Mesozoic time when southern Hainan (part of the Indochina block) collided with northern Hainan (part of South China). Alternatively, they could be formed in a volcanic rifted passive margin at the sea-floor spreading stage as part of MORB-like seaward-dipping reflector break-up packages.
\end{abstract}

Key words: Eastern Paleo-Tethys, geochemistry, Hainan Island, metabasites, Sm-Nd isotope, South China.

\section{INTRODUCTION}

South-east Asia constitutes one of the most complicated tectonic regions of the Earth, being a convergent triple junction at the global scale between the Pacific, Indo-Australian and Eurasian plates. It consists of a complex assembly of allochthonous continental blocks. These blocks rifted from the northern margin of Gondwanaland, drifted northwards, and eventually amalgamated to form the South-east Asian land mass during Paleozoic and Mesozoic time (Metcalfe 1996). These processes involved the opening and closing of successive

*Correspondence.

Received 21 May 2001; accepted for publication 12 March 2002.

(C) 2002 Blackwell Publishing Asia Pty Ltd. eastern Tethys oceans. Study of the suture zones and ophiolites between these blocks is particularly important for understanding the amalgamation and evolution of South-east Asia and eastern Tethys. So far, much attention has been paid to the ophiolites occurring along a few of major suture zones in South-east Asia, such as the Jinsha Suture (Chen \& Xie 1994; Jian et al. 1999), Shuanggou Suture (Zhang et al. 1994; Jian et al. 1998), Song Ma Suture (Hutchison 1989; Lepvrier etal. 1997), and Changning-Menglian Suture (Zhang et al. 1985; Liu et al. 1991; Wu et al. 1995; Fang et al. 1998).

Among these accreted blocks, Hainan Island is the least well understood as regards its nature and tectonic evolution. It is situated at the eastern flank of the South-east Asian continent (Fig.1), 
$194 \quad X-H . L i$ et al.

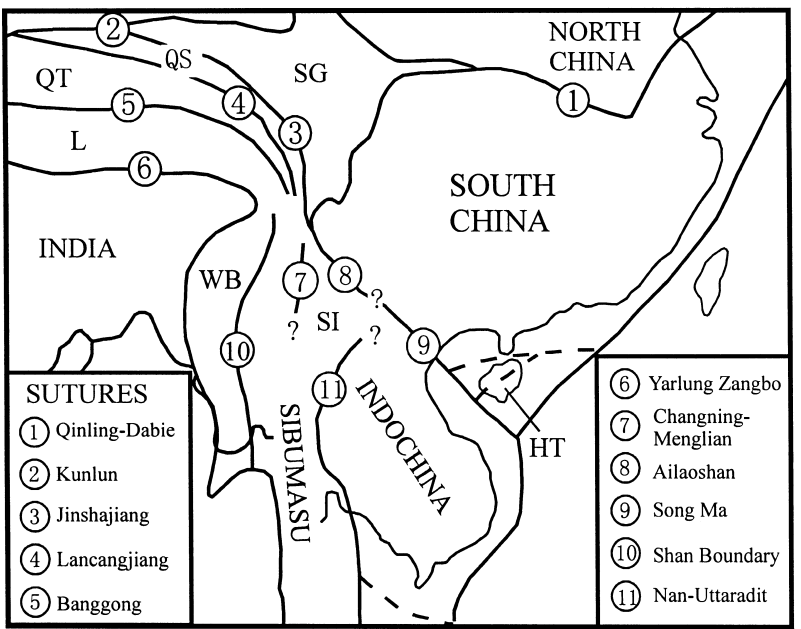

Fig. 1 Distributions of principal continental terranes and sutures of SE Asia (modified after Metcalfe 1996). QT, Qiangtang Terrane; QS, Qamdo-Simao Terrane; SG, Songpan Ganzi accretionary complex; L, Lhasa Terrane; WB, West Burma; SI, Simao Terrane; HT, Hainan Island terranes.

linking the South China and Indochina blocks (Metcalfe 1996). Although the island was generally considered to be the south-western end of the Cathaysia block in many Chinese studies (Shui 1987; Guangdong 1988; Zhang et al. 1990), other researchers considered Hainan Island to consist of two tectonostratigraphic terranes, with the boundaries of these still controversial. Yang et al. (1989) divided Hainan Island into a northern Qiongzhong terrane and a southern Yaxian terrane, bounded by the east-west-trending Jiushuo-Lingshui Fault (Fig.2a). Hsü et al. (1990) and Chen et al. (1992) interpreted the island as part of a Mesozoic orogenic belt formed by collision of the Gondwanaland-derived Dongnanya block (comprising the major part of Hainan Island) and the (South China) Huanan block. The 'Shilu Group' consists of tectonic mélange (Fig. 2b). Metcalfe et al. (1994) suggested that Hainan Island consists of two terranes, northwest Hainan and southeast Hainan, bounded by the southwestnortheast-oriented Baisha Fault (Fig. 2c). Finally, Xia et al. (1991) and Fang et al. (1992) proposed the east-west-trending Changjiang-Qionghai Fault in central Hainan as a Paleozoic rift (Fig. 2d). In the present paper we report major and trace element and $\mathrm{Sm}-\mathrm{Nd}$ isotopic data for metabasites from central Hainan Island. Our data demonstrate that these metabasites have typical normal (N)type mid-ocean ridge basalt (MORB) geochemical features, providing important constraints on the tectonic evolution of the island and the evolution of eastern Paleo-Tethys.
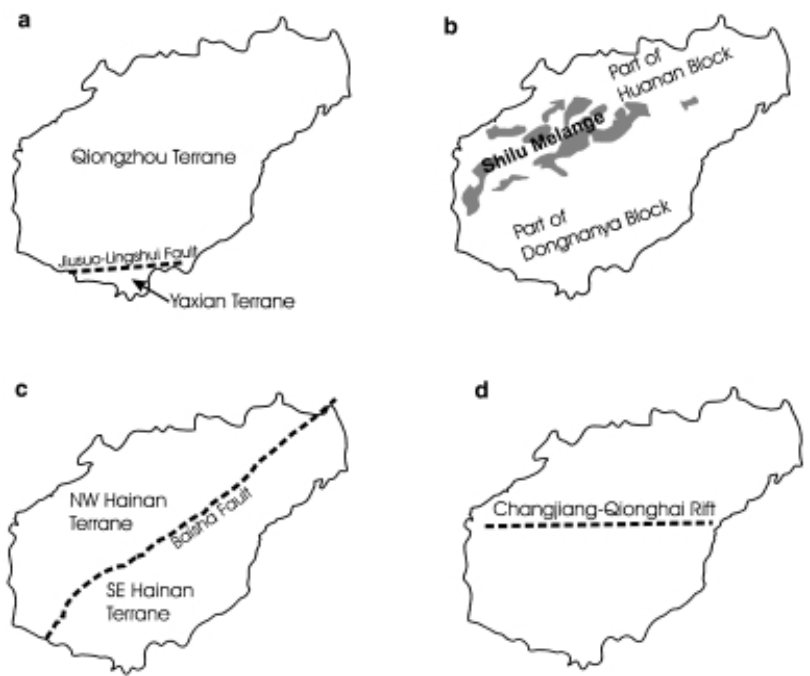

Fig. 2 Comparison of different tectonic models for Hainan Island. Two tectono-stratigraphic terranes, with different subdivisions, for the island were suggested by (a) Yang et al. (1989); (b) Hsü et al. (1990) and Chen et al. (1992); and (c) Metcalfe et al. (1994). Alternative Paleozoic rift model (d) was proposed by Xia et al. (1991) and Fang et al. (1992).

\section{GEOLOGICAL BACKGROUND}

Hainan Island, the second largest island in China, is a continental-type island, separated from the mainland by the Qiongzhou Strait (Fig.3). Proterozoic basement (the Baoban Group; Guangdong 1988 ) is exposed in the southwest of the island, and the Paleozoic strata crop out in the central band. Most of these Proterozoic and Paleozoic rocks, however, were re-interpreted as the 'Shilu Mélange' of late Paleozoic to early Mesozoic age by Hsü et al. (1990) and Chen et al. (1992; Fig. 2b). Mesozoic basins in the middle of the island trend northeast-southwest. Late Paleozoic-Mesozoic granites constitute more than $60 \%$ of the island's area. Cenozoic volcanic rocks are present in the north of the island. Three large east-westtrending faults, called, from north to south, the Wangwu-Wenjiao Fault, Changjiang-Qionghai Fault, and Jiusuo-Lingshui Fault, were inferred to be present in the island based on aeromagnetic data (Guangdong 1988).

Our recent field investigations identified a number of metabasites present as lenses within the Paleozoic metasediments exposed in two regions; that is, the Chenxing Farm in the Tunchang County and the Bangxi Farm in the Changjiang County at the northern side of the ChangjiangQionghai Fault (Fig.3). They are structurally enclosed by the Paleozoic metasediments. Clear fault contact was observed between the 


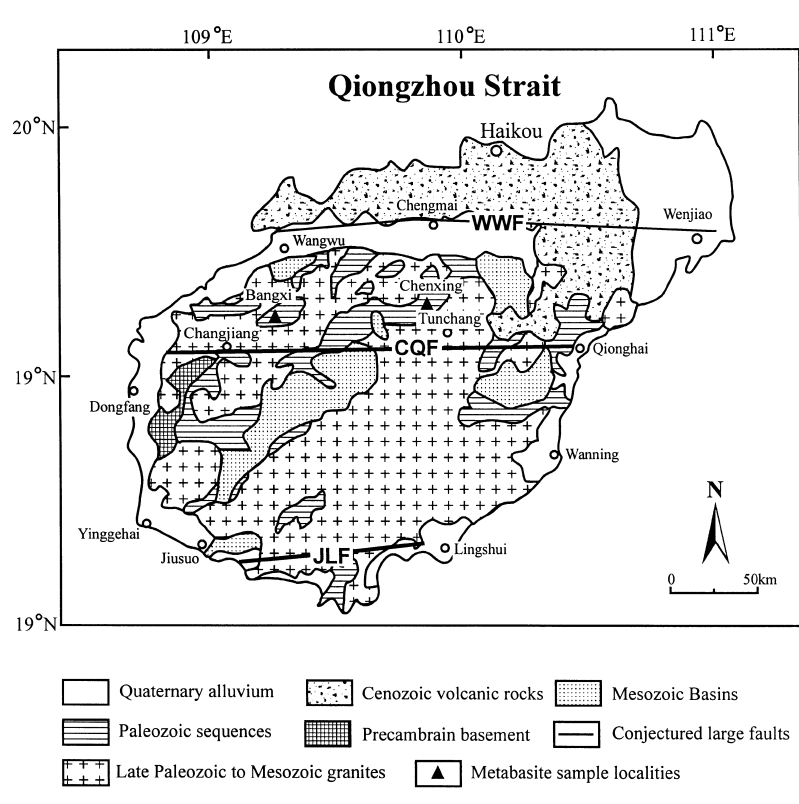

Fig. 3 Simplified geologic map of Hainan Island (modified after Guangdong 1988) illustrating the sample localities (triangles). WWF, Wangwu-Wenjiao Fault; CQF, Changjiang-Qionghai Fault; JLF, JiusuoLingshui Fault.

metabasites and the host phyllites, all of which are cut by granites of Late Paleozoic to early Mesozoic age (Hainan 1995). All Chenxing samples underwent metamorphism of amphibolite facies with a mineral assemblage of hornblende + plagioclase + diopside + biotite, and their original textures cannot be deciphered. Most Bangxi samples experienced metamorphism of greenschist facies, consisting of actinolite, chlorite, epidote and albite as well as a minor amount of apatite and Ti-Fe oxides. They generally have a hypidiomorphicgranular texture. Twinned plagioclase crystals can be observed in thin sections. Thus, plutonic protoliths are inferred for the Bangxi metabasites in terms of their petrographic features. The analyzed samples were altered to varying degrees with replacement of hornblende by tremolite.

\section{ANALYTICAL METHODS}

Major element oxides were determined using a Rigaku RIX 2000 X-ray fluorescence spectrometer (XRF) at the Department of Geology, National Taiwan University. Analytical precision as determined on duplicate analyses is generally approximately $1-5 \%$. The detailed analytical procedures for major element analysis by XRF were described by Lee et al. (1997).
Trace elements were analyzed using a PerkinElmer Sciex ELAN 6000 inductively coupled plasma mass spectrometer (ICP-MS) at the Guangzhou Institute of Geochemistry, Chinese Academy of Sciences. Approximately $50 \mathrm{mg}$ sample powders were dissolved in Teflon bombs using a $\mathrm{HF}+\mathrm{HNO}_{3}$ mixture for 2 days at $200^{\circ} \mathrm{C}$. An internal standard solution containing a singleelement $\mathrm{Rh}$ was used to monitor signal drift during counting. The US Geological Survey (USGS) standard BCR-1 was chosen to calibrate element concentrations of measured samples. Inrun analytical precision for most elements is better than $2 \%$. Detailed analytical procedures of inductively coupled plasma mass spectrometer (ICP-MS) were reported by Liu et al. (1996) and $\mathrm{Li}$ (1997).

The Nd isotopic compositions (unspiked aliquots) were determined using a multicollector Finnigan MAT-261 mass spectrometer operated in static multicollector mode at the Isotope laboratory of the China University of Geosciences (Wuhan). The measured ${ }^{143} \mathrm{Nd} /{ }^{144} \mathrm{Nd}$ ratios were normalized to ${ }^{146} \mathrm{Nd} /{ }^{144} \mathrm{Nd}=0.7219$. The ${ }^{143} \mathrm{Nd} /$ ${ }^{144} \mathrm{Nd}$ ratio of the La Jolla standard measured on this MAT-261 mass spectrometer during the present study was $0.511870 \pm 8(2 \sigma)$ on 20 runs. $\mathrm{Sm}-\mathrm{Nd}$ concentrations, spiked with mixed ${ }^{146} \mathrm{Nd}-$ ${ }^{149} \mathrm{Sm}$ tracers, were determined using a multicollector VG-354 mass spectrometer at the Guangzhou Institute of Geochemistry, Chinese Academy of Sciencies. Analytical precision for Sm and $\mathrm{Nd}$ concentrations and ${ }^{147} \mathrm{Sm} /{ }^{144} \mathrm{Nd}$ ratios is generally better than $0.5 \%$.

\section{RESULTS}

Ten least-altered metabasite samples were analyzed for major and trace elements. Eight of these were analyzed for $\mathrm{Sm}-\mathrm{Nd}$ isotopes. The elemental and $\mathrm{Sm}-\mathrm{Nd}$ isotopic results are listed in Table 1 and Table 2 , respectively.

\section{MAJOR AND TRACE ELEMENT GEOCHEMISTRY}

Because all metabasite samples were subject to greenschist- to amphibolite-facies metamorphism during which $\mathrm{K}, \mathrm{Na}$ and other low-field-strength elements are most likely changed, only immobile elements such as the high-field-strength elements, Th and rare earth elements (REE) are used to explore the magmatic affinity and petrogenesis. The metabasite samples have low $\mathrm{Zr} / \mathrm{TiO}_{2}(0.0045-$ 
$196 \quad X-H . L i$ et al.

Table 1 Major and trace element results for the metabasites from Hainan Island

\begin{tabular}{|c|c|c|c|c|c|c|c|c|c|c|}
\hline $\begin{array}{l}\text { Sample } \\
\text { Location }\end{array}$ & $\begin{array}{l}\text { cx-1 } \\
\text { CX }\end{array}$ & $\begin{array}{l}\text { cx-2 } \\
\text { CX }\end{array}$ & $\begin{array}{l}\text { cx-3 } \\
\text { CX }\end{array}$ & cx-4 & $\begin{array}{l}\text { cx-5 } \\
\text { CX }\end{array}$ & $\begin{array}{l}\text { cx-6 } \\
\text { CX }\end{array}$ & $\begin{array}{c}\mathrm{hn}-7 \\
\mathrm{BX}\end{array}$ & $\begin{array}{l}\text { b-1 } \\
\text { BX }\end{array}$ & $\begin{array}{l}\text { h-1 } \\
\text { BX }\end{array}$ & $\begin{array}{l}\mathrm{s}-3 \\
\mathrm{BX}\end{array}$ \\
\hline \multicolumn{11}{|c|}{ Major elements (wt\%) } \\
\hline $\mathrm{SiO}_{2}$ & 49.97 & 47.96 & 47.40 & 50.92 & 44.78 & 45.84 & 43.79 & 49.29 & 46.28 & 47.76 \\
\hline $\mathrm{TiO}_{2}$ & 0.56 & 0.62 & 0.41 & 0.39 & 0.50 & 0.47 & 0.94 & 0.63 & 0.95 & 2.02 \\
\hline $\mathrm{Al}_{2} \mathrm{O}_{3}$ & 12.24 & 14.62 & 13.43 & 12.63 & 15.41 & 15.21 & 11.12 & 13.59 & 15.79 & 16.52 \\
\hline$\Sigma \mathrm{Fe}_{2} \mathrm{O}_{3}$ & 9.80 & 10.06 & 9.79 & 7.97 & 11.00 & 10.59 & 14.44 & 11.01 & 12.22 & 11.78 \\
\hline $\mathrm{MnO}$ & 0.15 & 0.16 & 0.17 & 0.15 & 0.15 & 0.14 & 0.20 & 0.18 & 0.17 & 0.18 \\
\hline $\mathrm{MgO}$ & 13.18 & 12.32 & 11.64 & 10.71 & 13.78 & 11.94 & 21.04 & 13.72 & 13.24 & 8.63 \\
\hline $\mathrm{CaO}$ & 12.31 & 12.26 & 15.31 & 14.77 & 12.62 & 14.00 & 7.94 & 10.28 & 9.66 & 9.60 \\
\hline $\mathrm{Na}_{2} \mathrm{O}$ & 1.74 & 1.31 & 1.39 & 2.12 & 0.98 & 1.17 & 0.58 & 1.34 & 1.78 & 3.00 \\
\hline $\mathrm{K}_{2} \mathrm{O}$ & 0.19 & 0.82 & 0.63 & 0.50 & 0.93 & 0.79 & 0.01 & 0.06 & 0.01 & 0.45 \\
\hline $\mathrm{P}_{2} \mathrm{O}_{5}$ & 0.05 & 0.05 & 0.02 & 0.02 & 0.03 & 0.03 & 0.12 & 0.07 & 0.09 & 0.24 \\
\hline Total & 100.18 & 100.01 & 99.47 & 99.72 & 99.82 & 100.09 & 100.08 & 99.31 & 100.21 & 99.87 \\
\hline LOI & 1.52 & 2.16 & 3.02 & 2.52 & 3.29 & 2.54 & 3.50 & 2.29 & 2.80 & 1.22 \\
\hline $\mathrm{Mg} \#$ & 0.76 & 0.75 & 0.74 & 0.76 & 0.75 & 0.73 & 0.78 & 0.75 & 0.72 & 0.64 \\
\hline \multicolumn{11}{|c|}{ Trace elements (p.p.m.) } \\
\hline $\mathrm{Sc}$ & 32.9 & 34.7 & 31.8 & 31.5 & 38.7 & 38.2 & 22.4 & 35.1 & 43.6 & 37.8 \\
\hline $\mathrm{V}$ & 197 & 216 & 181 & 180 & 261 & 198 & 146 & 215 & 259 & 258 \\
\hline $\mathrm{Cr}$ & 887 & 881 & 1006 & 769 & 1192 & 1091 & 1091 & 859 & 825 & 290 \\
\hline Co & 59.9 & 59.0 & 58.0 & 46.5 & 60.5 & 55.5 & 81.9 & 64.8 & 64.7 & 49.0 \\
\hline $\mathrm{Ni}$ & 382 & 337 & 280 & 211 & 275 & 322 & 719 & 418 & 354 & 133 \\
\hline $\mathrm{Cu}$ & 48.9 & 29.3 & 56.8 & 14.6 & 80.0 & 94.8 & 81.4 & 97.9 & 86.5 & 72.0 \\
\hline $\mathrm{Zn}$ & 99.4 & 109 & 91.9 & 102 & 130 & 107 & 121 & 69.1 & 72.3 & 86.0 \\
\hline $\mathrm{Ga}$ & 9.91 & 12.0 & 9.42 & 8.09 & 13.0 & 11.9 & 13.0 & 13.1 & 17.8 & 19.2 \\
\hline $\mathrm{Rb}$ & 5.55 & 24.1 & 17.5 & 13.7 & 27.7 & 22.0 & 0.35 & 5.07 & 3.12 & 24.3 \\
\hline $\mathrm{Sr}$ & 141 & 136 & 172 & 189 & 89.9 & 154 & 9.76 & 143 & 149 & 315 \\
\hline $\mathrm{Y}$ & 17.2 & 18.9 & 14.0 & 12.7 & 16.9 & 14.9 & 16.5 & 16.4 & 23.6 & 33.9 \\
\hline $\mathrm{Zr}$ & 34.0 & 36.5 & 24.3 & 20.1 & 22.6 & 22.9 & 71.1 & 48.0 & 56.8 & 143 \\
\hline $\mathrm{Nb}$ & 0.48 & 0.50 & 0.42 & 0.35 & 0.32 & 0.42 & 4.40 & 1.70 & 2.63 & 9.00 \\
\hline $\mathrm{Cs}$ & 2.61 & 7.24 & 4.56 & 2.98 & 6.63 & 5.56 & 0.26 & 0.82 & 0.26 & 1.69 \\
\hline $\mathrm{Ba}$ & 18.9 & 138 & 51.7 & 45.1 & 80.8 & 28.7 & 1.34 & 15.5 & 56.0 & 198 \\
\hline $\mathrm{La}$ & 0.72 & 0.66 & 0.59 & 0.47 & 0.34 & 0.45 & 4.27 & 1.66 & 2.89 & 8.96 \\
\hline $\mathrm{Ce}$ & 2.37 & 2.15 & 1.39 & 1.30 & 0.95 & 1.29 & 9.67 & 4.58 & 7.45 & 23.6 \\
\hline $\operatorname{Pr}$ & 0.45 & 0.41 & 0.24 & 0.23 & 0.20 & 0.24 & 1.86 & 0.87 & 1.32 & 3.64 \\
\hline $\mathrm{Nd}$ & 3.09 & 2.94 & 1.87 & 1.71 & 1.67 & 1.86 & 8.67 & 4.67 & 6.74 & 17.0 \\
\hline $\mathrm{Sm}$ & 1.30 & 1.35 & 0.89 & 0.76 & 0.91 & 0.89 & 2.38 & 1.80 & 2.29 & 4.75 \\
\hline $\mathrm{Eu}$ & 0.56 & 0.32 & 0.38 & 0.41 & 0.41 & 0.42 & 1.00 & 0.64 & 1.08 & 2.08 \\
\hline $\mathrm{Gd}$ & 1.99 & 2.19 & 1.55 & 1.37 & 1.64 & 1.58 & 2.84 & 2.22 & 3.04 & 5.38 \\
\hline $\mathrm{Tb}$ & 0.39 & 0.44 & 0.32 & 0.29 & 0.35 & 0.33 & 0.46 & 0.40 & 0.58 & 0.92 \\
\hline Dy & 2.78 & 3.15 & 2.24 & 2.04 & 2.61 & 2.45 & 2.94 & 2.78 & 4.15 & 6.07 \\
\hline Ho & 0.63 & 0.71 & 0.48 & 0.47 & 0.61 & 0.56 & 0.60 & 0.58 & 0.87 & 1.21 \\
\hline Er & 1.88 & 2.07 & 1.49 & 1.41 & 1.80 & 1.68 & 1.78 & 1.69 & 2.53 & 3.39 \\
\hline $\mathrm{Tm}$ & 0.27 & 0.30 & 0.23 & 0.21 & 0.26 & 0.25 & 0.26 & 0.26 & 0.38 & 0.48 \\
\hline $\mathrm{Yb}$ & 1.85 & 2.03 & 1.57 & 1.49 & 1.76 & 1.74 & 1.67 & 1.69 & 2.48 & 3.08 \\
\hline $\mathrm{Lu}$ & 0.30 & 0.32 & 0.25 & 0.25 & 0.28 & 0.27 & 0.24 & 0.23 & 0.37 & 0.44 \\
\hline $\mathrm{Hf}$ & 0.91 & 0.99 & 0.62 & 0.54 & 0.59 & 0.64 & 1.94 & 1.35 & 1.53 & 3.89 \\
\hline $\mathrm{Ta}$ & 0.028 & 0.030 & 0.024 & 0.021 & 0.018 & 0.025 & 0.24 & 0.10 & 0.16 & 0.58 \\
\hline Th & 0.020 & 0.027 & 0.031 & 0.019 & 0.029 & 0.026 & 0.26 & 0.15 & 0.21 & 0.75 \\
\hline $\mathrm{U}$ & 0.06 & 0.07 & 0.11 & 0.06 & 0.34 & 0.26 & 0.09 & 0.14 & 0.07 & 0.19 \\
\hline
\end{tabular}

Note: Major elements are in dry system. $\mathrm{Mg} \#=\mathrm{Mg} /\left(\mathrm{Mg}+\mathrm{Fe}^{2+}\right)$, assuming $\mathrm{Fe}_{2} \mathrm{O}_{3} /\left(\mathrm{FeO}_{+} \mathrm{Fe}_{2} \mathrm{O}_{3}\right)=0.20$. Total iron as $\mathrm{Fe}_{2} \mathrm{O}_{3}$. $\mathrm{CX}=$ Chenxing; BX = Bangxi.

$0.0076)$ and $\mathrm{Nb} / \mathrm{Y}(0.03-0.3)$ ratios, similar to those of tholeiitic basalts (Winchester \& Floyd 1976). In the $\mathrm{Zr} / \mathrm{TiO}_{2}$ versus $\mathrm{SiO}_{2}$ diagram of Winchester and Floyd (1976), all but one of the samples (HN7) plot within the subalkaline field (Fig.4).

These metabasites can be subdivided into two groups in terms of major and trace element geochemistry, as shown in the Harker-type $\mathrm{MgO}$ variation diagrams (Fig. 5). Group 1, including all six Chenxing samples and two Bangxi samples (H1 and B-1), display coherent variations for most major and trace elements. The remaining two Bangxi samples, HN-7 and S-3, referred to here as group 2, plot as outliers in composition from the 
Table $2 \mathrm{Sm}-\mathrm{Nd}$ isotopic data for the metabasites from Hainan Island

\begin{tabular}{lccccc}
\hline Sample & Sm (p.p.m.) & Nd (p.p.m.) & ${ }^{147} \mathrm{Sm} /{ }^{14} \mathrm{Nd}$ & ${ }^{143} \mathrm{Nd} /{ }^{144} \mathrm{Nd} \pm 2 \sigma_{\mathrm{m}}$ & $\varepsilon \mathrm{Nd}(\mathrm{T})$ \\
\hline CX-1 & 1.27 & 3.15 & 0.2445 & $0.513083 \pm 0.000011$ & 6.66 \\
CX-2 & 1.40 & 2.86 & 0.2953 & $0.513194 \pm 0.000011$ & 6.66 \\
CX-3 & 0.870 & 1.89 & 0.2777 & $0.513158 \pm 0.000018$ & 6.71 \\
CX-5 & 0.943 & 1.80 & 0.3167 & $0.513243 \pm 0.000016$ & 6.57 \\
CX-6 & 0.881 & 1.88 & 0.2834 & $0.513171 \pm 0.000012$ & 6.72 \\
B-1 & 1.80 & 4.97 & 0.2188 & $0.513038 \pm 0.000013$ & 6.87 \\
S-3 & 4.88 & 17.2 & 0.1720 & $0.512929 \pm 0.000006$ & 6.74 \\
HN-7 & 2.43 & 8.81 & 0.1670 & $0.512913 \pm 0.000009$ & 6.64 \\
JYVR* & 2.29 & 5.85 & 0.2365 & $0.513074 \pm 0.000011$ & 7.06 \\
\hline
\end{tabular}

${ }^{143} \mathrm{Nd} /{ }^{144} \mathrm{Nd}$ ratios are further adjusted relative to La Jolla standard $=0.511860 ; \mathrm{T}=\mathrm{Sm}-\mathrm{Nd}$ whole-rock isochron age of $333 \pm 12 \mathrm{Ma}$, representing the crystallization age of the metabasites.

*Data after Fang et al. (1992).

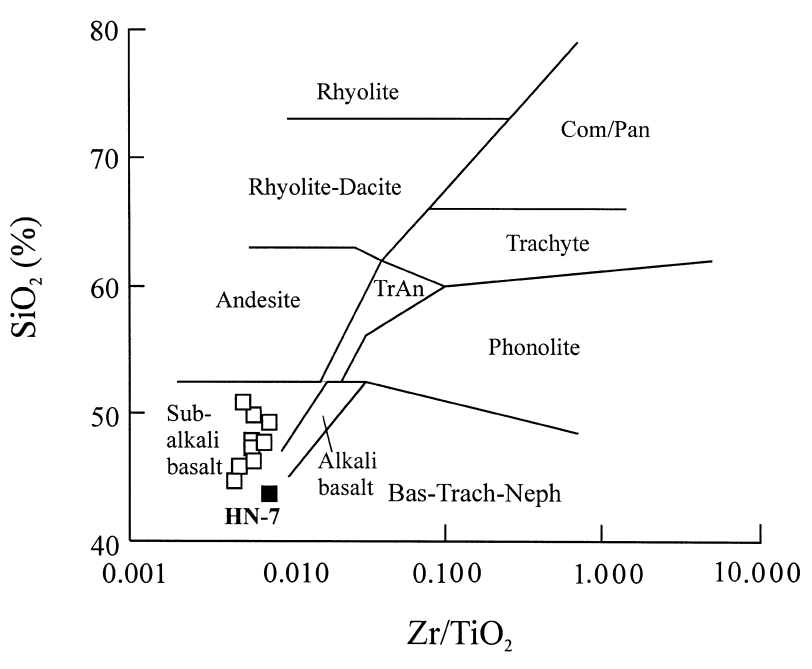

Fig. $4 \quad \mathrm{SiO}_{2}$ versus $\mathrm{Zr} / \mathrm{TiO}_{2}$ diagram (Winchester \& Floyd 1976) for classification of the Bangxi-Chenxing metabasites. Bas-Trach-Neph, basanite-trachybasanite-nephelinite; TrAn, trachyandesite; Com/Pan, comendite/pantellerite.

coherent trends of group 1 samples. In the chondrite-normalized REE distribution diagram (Fig.6), the metabasite samples have a relatively small range of heavy REE (HREE) abundances, but significantly variable light REE (LREE) depletion. Group 1 samples display LREEdepleted patterns, with the Chenxing samples having the lowest LREE abundance and a chondrite-normalized $(\mathrm{La} / \mathrm{Yb})_{\mathrm{N}}$ ratio $=0.13-0.26$. In contrast, group 2 samples have higher LREE abundance and nearly flat REE patterns. Such LREE depletion to varying degrees indicates that these metabasites could have been generated by relatively large degrees of partial melting of depleted mantle source, similar to the basaltic rocks in MORB and intra-arc/back-arc basin. Group 2 sample $\mathrm{HN}-7$ has the highest $\mathrm{MgO}$ (21.04\%) and Ni (719 p.p.m) but medium high $\mathrm{Cr}$
(1091 p.p.m), indicating significant amounts of olivine accumulation. In contrast, the other group 2 sample S-3 has relatively lower $\mathrm{MgO}$ (8.63\%), Ni (133 p.p.m) and Cr (290 p.p.m).

It is noted that the group 1 samples generally have a high $\mathrm{MgO}$ content (10.71-13.78\%), which is significantly more magnesian than the vast bulk of the $\mathrm{MORB}$, which rarely have $\mathrm{MgO}>10 \%$ (Fig. 5). There are significant differences in trends and major element compositions between group 1 samples and MORB (Fig. 5). These major element features suggest that group 1 metabasites were not typical MORB lavas. Group 1 samples show a deviation from the MORB spread in the direction of the clinopyroxene-dominated clinopyroxeneolivine mixture line, indicating that they were likely to be orthocumulate gabbroic rocks. Increase of $\mathrm{Cr}, \mathrm{V}$ and $\mathrm{Sc}$ with increasing $\mathrm{MgO}$ also suggests the clinopyroxene-dominated accumulation for group 1 samples (Fig.5). Such clinopyroxene- and olivine-enriched cumulate gabbros are similar in major elements to the abundant gabbros in arc crust, particularly in intraoceanic arc such as the Mariana arc, but significantly different from the gabbro in mid-ocean ridge oceanic crust (Fig. 5).

Figure 7 shows the primitive mantle-normalized trace element variation patterns for the studied metabasites. Group 1 samples show varying degrees of depletion of Th, Nb, Ta and LREE, with the Chenxing samples having abundances of these elements that are even lower than those of primitive mantle. In contrast, group 2 metabasites have a relatively higher abundance of trace elements and less depletion of these highly incompatible trace elements, resembling those of enriched (E)-type MORB (Sun \& Mcdonough 1989). Sample HN-7 has a relatively lower abundance of most 
$198 \quad X-H . L i$ et al.
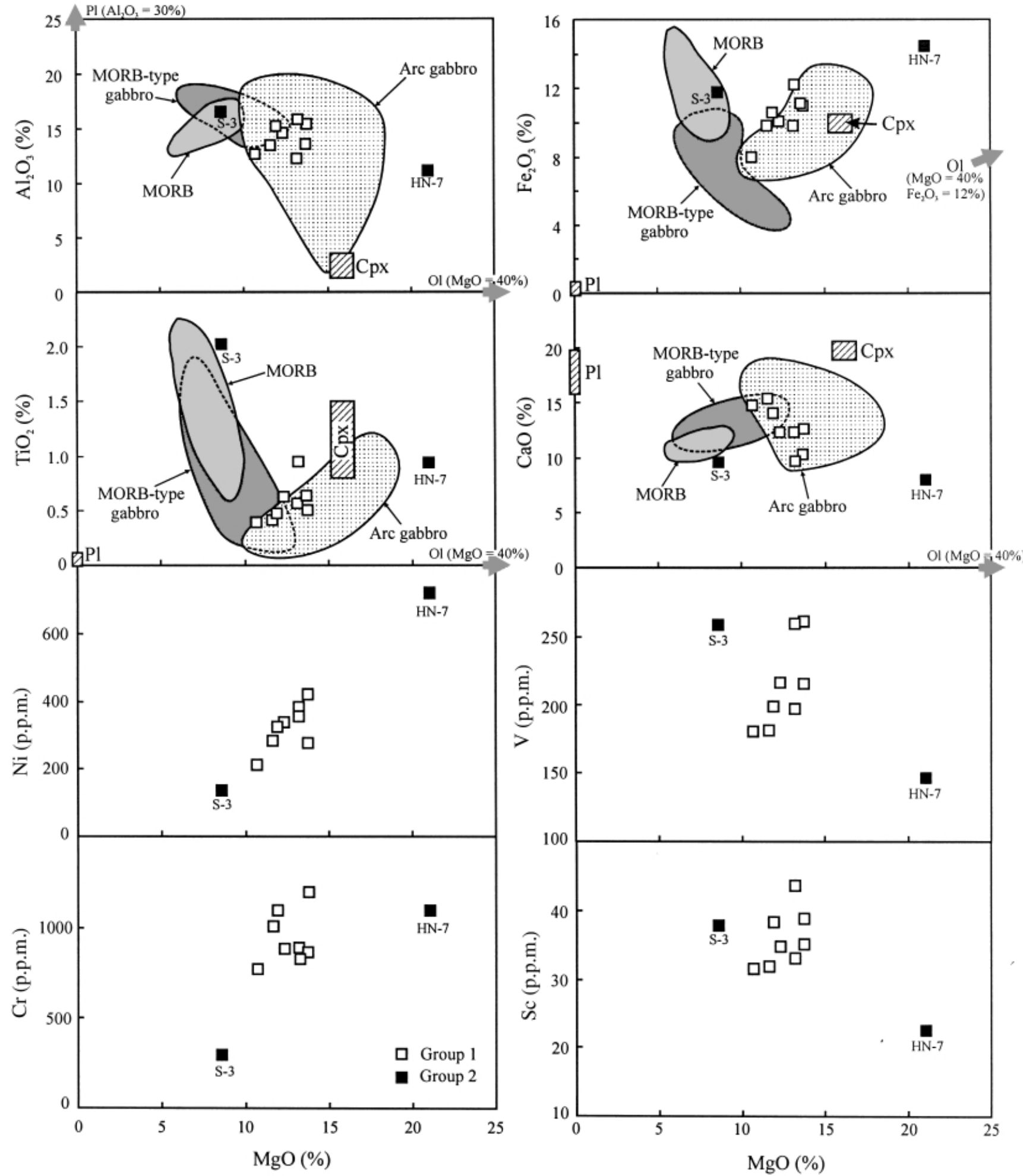

Fig. 5 Major and trace elements versus Mg0 variation diagram for the Bangxi-Chenxing metabasites, comparing with the major elements for mid-ocean ridge basalt (MORB) glass and gabbros (with Mg0 $>10 \%$ ) in the Pacific MORB-type and in the Mariana arc (arc-type). Data source: (1) MORB glasses are after Miyashiro et al. (1969), Hekinian (1971), Shido et al. (1974), Hermes \& Schilling (1976); Dickey et al. (1977), Batiza et al. (1988), Humler and Whitechurch (1988), Sinton et al. (1993), and Bach et al. (1996); (2) MORB-type gabbros are after Engel \& Fisher (1969, 1975), Wood et al. (1978), Tarney et al. (1979), Saunders et al. (1982), Hebert et al. (1983), and Weaver et al. (1985); (3) arc-type gabbros are after Dietrich et al. (1978), Meijer and Reagan (1981), Woodhead (1988), and Newman et al. (2000). 


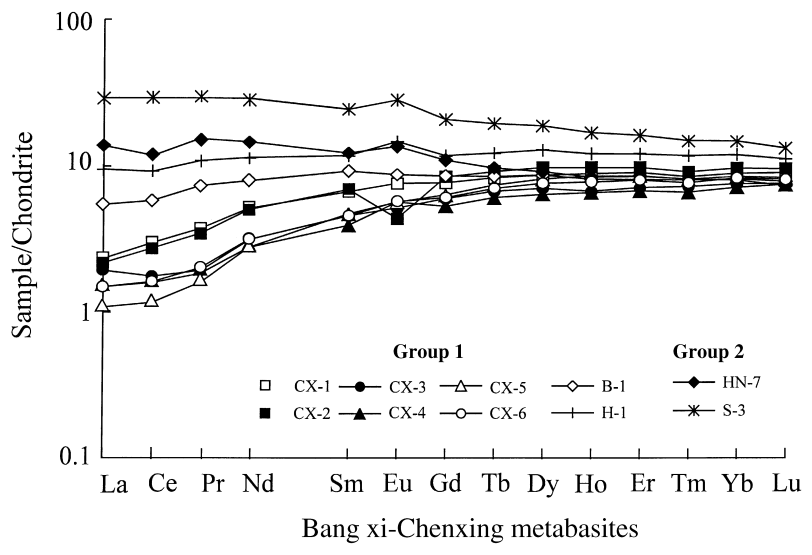

Fig. 6 Chondrite-normalized rare earth element (REE) diagrams for the Bangxi-Chenxing metabasites. Normalization values after Sun and McDonough (1989).

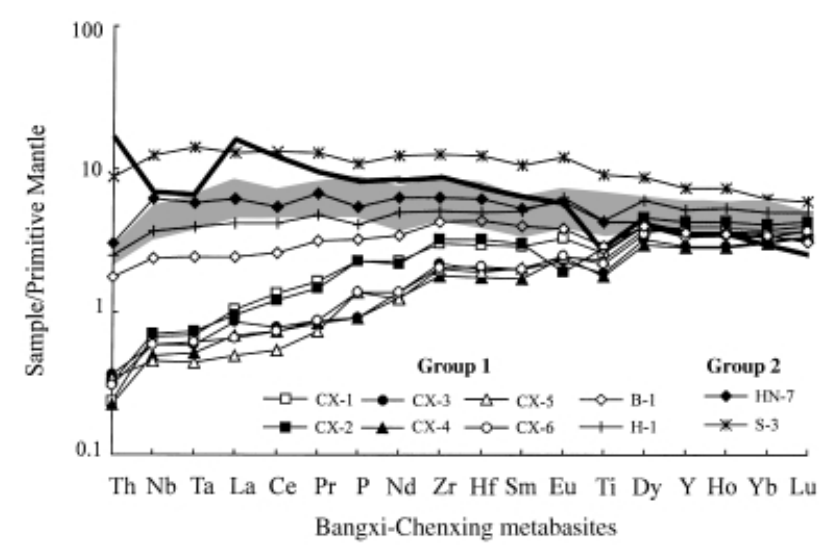

Fig. 7 Primitive mantle-normalized trace element spidergram for the Bangxi-Chenxing metabasites, comparing with the mid-ocean ridge basalt (MORB)- (shaded) and arc-type (bold line) gabbros. Normalization values after Sun and McDonough (1989). Data sources: (1) MORB-type gabbro are after Saunders et al. (1982) and Spadea et al. (1991); (2) arctype gabbro is a representative sample (90AMM300I) from the Aleutian arc after Nye et al. (1994).

trace elements possibly due to olivine accumulation. It is noted that all the metabasite samples have trace element patterns significantly different from the arc gabbros (elevated Th and LREE and significant $\mathrm{Nb}-\mathrm{Ta}$ negative anomaly), with group 1 samples B-1 and $\mathrm{H}-1$ resembling the MORB-type gabbros (Fig. 7).

In summary, the Bangxi-Chenxing metabasites appear to be metamorphosed cumulated gabbroic rocks with major element variations similar to arc gabbros but trace element features resembling $\mathrm{N}$ MORB. They can be subdivided into two groups in terms of major and trace element characteristics, with group 1 metabasites showing more depleted geochemical features than those of group 2 .

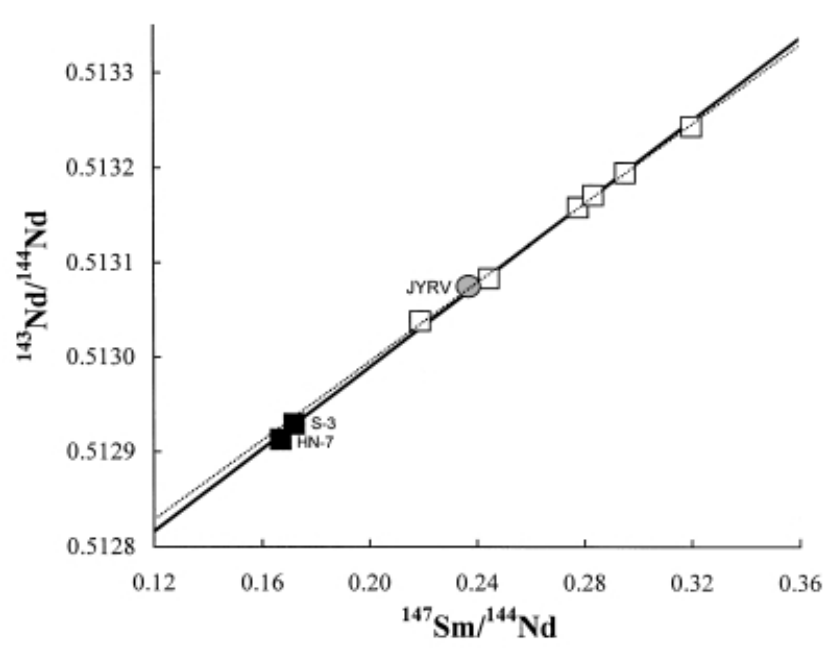

Fig. 8 Sm-Nd isochron diagram for the Bangxi-Chenxing metabasites. Sm-Nd isochron age and $\in \mathrm{Nd}(\mathrm{T})$ values were calculated using Isoplot/Ex after Ludwig (1998), where 0.5\% was chosen as the error of ${ }^{147} \mathrm{Sm} /{ }^{144} \mathrm{Nd}$ ratios. Errors are quoted at the $2 \sigma$ level. (---) Group 1 samples (7 data): age $=320 \pm 24 \mathrm{Ma}, \in \mathrm{Nd}(\mathrm{T})=6.9 \pm 0.8, \mathrm{MSWD}=0.30$. (一) All samples (9 data): age $=333 \pm 12 \mathrm{Ma}, \in \mathrm{Nd}(\mathrm{T})=6.7 \pm 0.4$, $M S W D=0.48$.

\section{SM-ND ISOTOPES}

Group 1 metabasites, including one sample (JYVR) from Junying in western Bangxi reported by Fang et al. (1992), have high and variable ${ }^{147} \mathrm{Sm} /$ ${ }^{144} \mathrm{Nd}$ ratios $(0.2188-0.3199)$, which are higher than the chondritic value of 0.1967 . In contrast, group 2 samples have relatively low and uniform ${ }^{147} \mathrm{Sm} /{ }^{144} \mathrm{Nd}$ ratios $(0.1670-0.1720)$. In the conventional Sm-Nd isochron diagram (Fig.8), seven group 1 samples yield a $\mathrm{Sm}-\mathrm{Nd}$ isochron age of $320 \pm 24 \mathrm{Ma}$ and an initial $\in \mathrm{Nd}(\mathrm{T})$ value of $+6.9 \pm 0.8$. Two group 2 samples, which cannot be regressed for an isochron owing to limited ${ }^{147} \mathrm{Sm} /$ ${ }^{144} \mathrm{Nd}$ variation, plot along the lower extension of the isochron of group 1 samples. All nine samples yield a Sm-Nd isochron age of $333 \pm 12 \mathrm{Ma}$ and an $\in \mathrm{Nd}(\mathrm{T})$ value of $+6.7 \pm 0.4$, which are indistinguishable within error from those of the sevenpoint isochron of group 1 samples. It should be noted that the $\mathrm{Sm}-\mathrm{Nd}$ isotopic system can behave as an open system during metamorphism (Vervoort et al. 1996), although REE are generally immobile in most crustal processes. In order to properly interpret the geologic meaning of the aforementioned $\mathrm{Sm}-\mathrm{Nd}$ isochron age, it is necessary to verify if the $\mathrm{Sm}-\mathrm{Nd}$ system of the metabasites has been modified during subsequent greenschist to amphibolite metamorphism.

As mentioned earlier, group 1 samples have very low LREE contents and display LREEdepleted patterns, resembling those of N-MORB. 
If the Sm-Nd system of these samples has been modified through interaction with the crustal fluids during metamorphism, a small amount of crustal contamination (with a typical average crustal value of 25 p.p.m. Nd) would significantly increase their LREE contents and consequently change their REE patterns and $\mathrm{Nd}$ isotopic compositions. However, such elevated LREE patterns were not seen in these samples. In addition, MORB and oceanic island tholeiite (OIT) commonly have $\mathrm{Nb} / \mathrm{Th}$ of $14-20$ (Sun \& McDonough 1989), whereas the crustal rocks have much lower $\mathrm{Nb} / \mathrm{Th}$ values, with the average crust having an $\mathrm{Nb} / \mathrm{Th}$ of approximately 3 (Taylor \& McLennan 1985). The Hainan metabasites have $\mathrm{Nb} / \mathrm{Th}$ values of 11-24, with most samples being between 13 and 19, comparable with those of MORB and OIT. The slightly wider range of $\mathrm{Nb} / \mathrm{Th}$ is possibly due to analytical uncertainties associated with the very low $\mathrm{Nb}$ and $\mathrm{Th}$ contents.

The immobility of REE for the metabasites indicates that the $\mathrm{Sm}-\mathrm{Nd}$ whole-rock isochron age of $333 \pm 12 \mathrm{Ma}$ can be interpreted as the crystallization age, rather than the metamorphic age, of these samples. High $\in \mathrm{Nd}(\mathrm{T})$ values of approximately +7 indicate that these metabasites were derived from a highly depleted mantle source without continental crust contamination. The MORB-type mantle is estimated to have had an $\in \mathrm{Nd}(\mathrm{T})$ value of $+9 \pm 2$ at $\mathrm{T}=330 \mathrm{Ma}$, assuming its present average $\in \mathrm{Nd}(0)$ value of $+10 \pm 2$ evolved linearly from a chondritic source since the Early Archean $(4.0 \mathrm{Ga})$. Thus, the initial $\in \mathrm{Nd}(\mathrm{T})$ value of approximately +7 for the Bangxi-Chenxing metabasites is marginally within the range of the expected value for Carboniferous MORB. Although the two groups of Bangxi-Chenxing metabasites have different trace element features, they were probably generated contemporaneously from MORB-like mantle sources with similar $\mathrm{Nd}$ isotopic compositions, or possibly from the same MORB-like mantle source.

\section{DISCUSSION}

\section{PETROGENESIS}

The aforementioned geochemical and $\mathrm{Nd}$ isotopic data indicate that all metabasite samples analyzed in the present study show MORB affinity, most likely originating from MORB-like mantle sources. Such MORB-like mafic rocks are commonly formed in the oceanic settings, for example along mid-ocean ridges and in mature intra-arc or back-arc basins, rather than in continental or island arc regimes. But given the unique high positive $\in \mathrm{Nd}(\mathrm{T})$ value of approximately +7 , these metabasites, however, display apparent differences in their major and trace elements, with group 1 and group 2 samples having trace element features similar to N-type and E-type MORB, respectively. Geochemical variations of these metabasites point to a role of (i) source heterogeneity; (ii) variable degrees of partial melting; and (iii) fractional crystallization in their petrogenesis and genetic relations.

Sun et al. (1979) demonstrated that $\mathrm{Al}_{2} \mathrm{O}_{3} / \mathrm{TiO}_{2}$ and $\mathrm{CaO} / \mathrm{TiO}_{2}$ in relatively primitive MORB vary with the degree of partial melting and the nature of the source region. In the $\mathrm{Al}_{2} \mathrm{O}_{3} / \mathrm{TiO}_{2}$ and $\mathrm{CaO} /$ $\mathrm{TiO}_{2}$ versus $\mathrm{TiO}_{2}$ diagrams (Fig.9), all samples
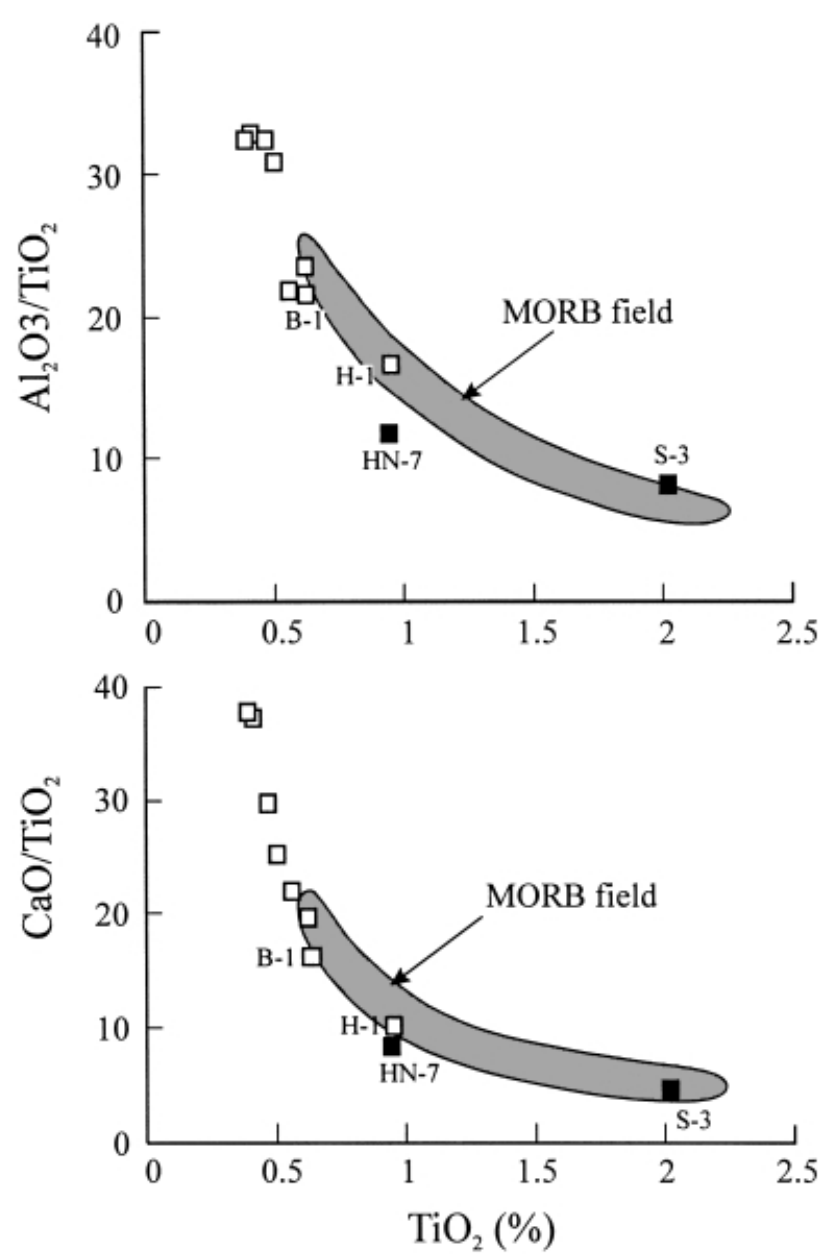

Fig. $9 \quad \mathrm{Al}_{2} \mathrm{O}_{3} / \mathrm{TiO}_{2}$ and $\mathrm{CaO} / \mathrm{TiO}_{2}$ versus $\mathrm{TiO}_{2}$ diagrams for the BangxiChenxing metabasites. The shaded area indicates mid-ocean ridge basalt (MORB) field confined by the MORB glasses (Data sources are the same as in Fig. 5). 
have a curved negative correlation. Two group 1 samples (B-1 and H-1) plot within the MORB field with relatively primitive compositions of major and trace elements. They were likely generated by relatively large (approx. 20\%) degrees of partial melting from a depletd source (Jaques \& Green 1980). Most Chenxing samples have high $\mathrm{Al}_{2} \mathrm{O}_{3} /$ $\mathrm{TiO}_{2}(>25)$ and $\mathrm{CaO} / \mathrm{TiO}_{2}(>20)$ exceeding values of the MORB field, probably due to larger degrees of partial melting from a relatively more depleted mantle source (Sun et al. 1979). Sample S-3 has high abundances of $\mathrm{Al}_{2} \mathrm{O}_{3}, \mathrm{TiO}_{2}, \mathrm{P}_{2} \mathrm{O}_{5}$ and most incompatible trace elements, and the lowest $\mathrm{Al}_{2} \mathrm{O}_{3}$ / $\mathrm{TiO}_{2}$ and $\mathrm{CaO} / \mathrm{TiO}_{2}$ ratios, indicating derivation from smaller degrees of partial melting accompanied by some subsequent crystal fractionation of pyroxene and/or olivine. Sample HN-7 probably contains accumulated olivine from an incompatible element-enriched magma, probably similar to the parent magma of sample S-3, because of its relatively high contents of $\mathrm{TiO}_{2}, \mathrm{P}_{2} \mathrm{O}_{5}$ and most incompatible trace elements.

In the La/Sm versus La diagram (Fig. 10), which has proven useful in distinguishing the effects of partial melting from fractional crystallization (Allègre \& Minster 1978), all but one of the samples (S-3) follow a partial melting trend. With decreasing chondrite normalized $(\mathrm{La} / \mathrm{Sm})_{\mathrm{n}}$ ratios from $>1$ for samples HN-7 and S-3, through 0.60.8 for samples B-1 and $\mathrm{H}-1$ down to $0.24-0.43$ for the Chenxing samples, parent magmas of these metabasites were likely generated by a

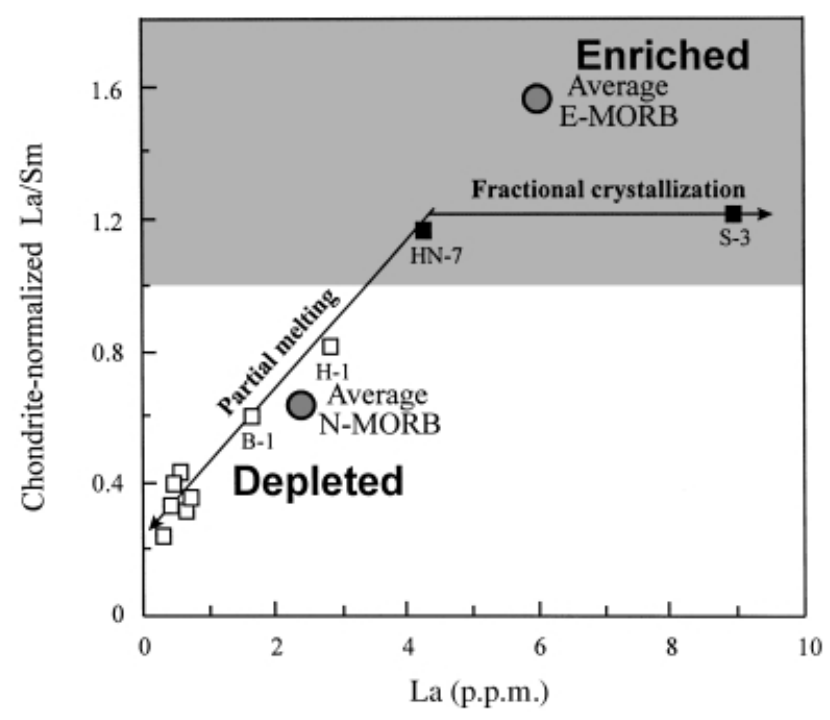

Fig. 10 Chondrite-normalized $\mathrm{La} / \mathrm{Sm}$ versus $\mathrm{La}$ diagram for the Bangxi-Chenxing metabasites. dynamic melting process similar to that described in Langmuir et al. (1977).

\section{TECTONIC IMPLICATIONS}

\section{Remnants of fragmented oceanic crust in Hainan}

Our geochemical and Sm-Nd isotopic data demonstrate that the Bangxi-Chenxing metabasites with MORB affinity were formed in an oceanic environment. They were cumulated gabbroic rocks that might have been crystallized from MORB-like magmas in an intraoceanic arc basin. Thus, these metabasites are most likely remnants of fragmented oceanic crust. These oceanic crust fragments, possibly as part of a mafic member of an unidentified ophiolite suite, were obducted onto the continental crust during closure of the ocean basin, which has significant implications for the tectonic evolution of Hainan Island and surrounding areas.

Identification of the Bangxi-Chenxing metabasites with MORB affinity indicates that Hainan Island was separated by an oceanic basin in late Paleozoic time; that is, the southern and northern Hainan blocks (Hsü et al. 1990; Chen et al. 1992). The Bangxi-Chenxing metabasites crop out within the 'Shilu mélange', which Hsü et al. (1990) and Chen et al. (1992) proposed as representing a Mesozoic orogenic belt formed by collision of the Indochina and South China blocks (Fig. 2B). The presence of metabasites with MORB affinity lends support to this tectonic model. The Sm-Nd isochron age of $333 \pm 12 \mathrm{Ma}$ for these metabasites has placed a maximum age limit on the timing of the collision between the southern and northern Hainan blocks.

In contrast, it is worthwhile to note that the Bangxi-Chenxing metabasites are coeval with the Carboniferous tholeiites along the southern side of the Changjiang-Qionghai Fault; the latter, associated with rhyolites and having intraplate geochemical characteristics, LREE enrichment and $\in \mathrm{Nd}(\mathrm{T})$ values of +6.9 to +7.7 , have been interpreted as a rift-related bimodal volcanic suite (Fang et al. 1992). Thus, it is possible that the MORB-like metabasites and the intraplate tholeiites could be generated by the same magmatic event during the middle Carboniferous (i.e. the central Hainan started as a rift and then developed into an ocean). Such a tectono-magmatic scenario seems analogous to the volcanic rifted passive margin off northwestern Australia (Colwell et al. 1994; Crawford \& von Rad 1994). 
The Chenxing metabasites are similar to the strongly depleted basalts drilled at Ocean Drilling Program (ODP) Sites 765 and 766, both having more extreme compositional characteristics (lower $(\mathrm{La} / \mathrm{Sm})_{\mathrm{N}}$ and $\mathrm{Ti} / \mathrm{Zr}$ values (averaging 110) than the typical N-MORB. In this volcanic rifted passive margin regime, the intraplate tholeiites were generated at the earlier rift stage, while the Bangxi-Chenxing MORB-like metabasites formed at the later sea-floor spreading stage as part of the MORB-like seaward-dipping reflector break-up packages (Crawford \& von Rad 1994). The juxtaposition of the MORB-like metabasites with the intraplate tholeiites in central Hainan might be caused by incorporation of both into a fold belt during later arc-continent or continent-continent collision.

\section{Comparison with the eastern Paleo-Tethys ophiolites}

It is widely accepted that the Song Ma ophiolite in northern Vietnam and the Shuanggou ophiolites in western Yunnan are correlative and together represent the main plate boundary between the Indochina and South China blocks (Zhang et al. 1994; Chung et al. 1999; Lan et al. 2000). The age of ophiolites exposed in the suture zones and the collision time of the two blocks have not yet been well-constrained. Recently, Lepvrier et al. (1997) showed through ${ }^{40} \mathrm{Ar}-{ }^{39} \mathrm{Ar}$ dating that all members of the Song Ma Ophiolite share the same metamorphic age of ca $245 \mathrm{Ma}$, implying suturing between Indochina and South China in the earliest Triassic. Jian et al. (1998) reported U-Pb zircon dates of $362 \pm 41 \mathrm{Ma}$ for gabbro and $328 \pm 16 \mathrm{Ma}$ for plagiogranite from the Shuanggou Ophiolite, which may indicate the formation ages of the ophiolite. Moreover, Jian et al. (1999) also obtained $\mathrm{U}-\mathrm{Pb}$ zircon ages of $340 \pm 3 \mathrm{Ma}$ for anorthosite from the Jinsha Ophiolite, and interpreted that the Jinsha Ophiolite can be correlated with the Shuanggou Ophiolite. The Jinsha Ophiolite is thus regarded as the northwestern extension of the Shuanggou Ophiolite (Jian et al. 1999). These data indicate the presence of an oceanic plate (i.e. the eastern Paleo-Tethys) between Indochina and South China during the Carboniferous. Before the suturing of the two blocks that occurred in the earliest Triassic (Lepvrier et al. 1997), the PaleoTethyan plate may have subducted beneath the Indochina block, which resulted in a magmatic arc along the Indochina margin (Chung et al. 1999; Lan et al. 2000). It is interesting to note that the Bangxi-Chenxing MORB-like metabasites in central Hainan are broadly synchronous with the ophiolites in the Jinsha-Shuanggou-Song Ma sutures (Hutchison 1989; Zhang et al. 1994; Lepvrier et al. 1997; Jian et al. 1998, 1999), and the proposed Shilu mélange (Hsü et al. 1990; Chen et al. 1992) seems coeval with the early phase of the Indosinian orogeny. Furthermore, basaltic rocks from the Shuanggou and Song Ma ophiolites also have MORB-type geochemical affinities (Zhang et al. 1994; Chung et al. 1999). Such similarities in age may imply a common petrogenetic process and tectonic backgroud. Therefore, the Bangxi-Chenxing MORB-like metabasites in central Hainan Island may represent the remnant oceanic crust of the easternmost part of PaleoTethys. Consequently, Hainan Island is most likely composed of two blocks, similar to the interpretation of Hsü et al. (1990) and Chen et al. (1992). The southern and northern Hainan blocks are correlated with the Indochina and South China blocks, respectively. In this interpretation, Hainan Island is thus neither an independent terrane (Metcalfe 1996), nor the southwestern end of Cathaysia (Shui 1987; Guangdong 1988; Zhang et al. 1990). It should be pointed out, however, that a complete ophiolitic suite (including ultramafic mantle peridotite and deep-sea sediments and cherts) has not yet been identified in central Hainan. Such a tectonic model can be further tested by the following work: (i) detailed field investigations to identify whether a late Paleozoic ophiolitic suite exists in the Shilu mélange; (ii) a more comprehensive comparison of the geology of the northern and southern Hainan blocks with that of the Huanan and Indochina blocks in nearby regions; and (iii) geochronological and geochemical study of late Paleozoic to Mesozoic intrusives and extrusives on Hainan (Guangdong 1988).

\section{ACKNOWLEDGEMENTS}

Thanks are extended to the Hainan Geological Survey for assistance in field work, and Wenli Lin, Xianglin Tu and Ganlin Wang for assistance in Sm-Nd isotope and trace element analyses. Zheng-Xiang Li is particularly thanked for his thoughtful and constructive discussions during our research on Hainan Island. Comments by Eldridge Moores and Zheng-Xiang Li on an early version of this paper were helpful. XHL thanks the Australian Academy of Sciences for providing a 3-month visiting fellowship to the University of Western Australia under the agreement of 
scientific cooperation between the Chinese and Australian Academies of Sciences, which resulted in the final completion of this paper. Reviews and constructive comments by A. J. Crawford and S-S. Sun have substantially improved the manuscript. This work was co-supported by the Chinese Academy of Sciences (grants KZCX2-102 and KZ952-J1-408) and National Natural Science Foundation of China (grants 49725309, 40032010-B and 49772094).

\section{REFERENCES}

Allègre C. J. \& Minster J. F. 1978. Quantitative models of trace element behavior in magmatic processes. Earth and Planetary Science Letters 38, $1-25$.

BACH W., Erzinger J., Dosso L. et al. 1996. Unusually large $\mathrm{Nb}-\mathrm{Ta}$ depletions in North Chile Ridge basalts at $36^{\circ} 50^{\prime}$ to $38^{\circ} 56^{\prime}$, major element, trace element, and isotopic data. Earth and Planetary Science Letters 142, 223-40.

Batiza R., Melson W. G. \& O’Hearn T. 1988. Simple magma supply geometry inferred beneath a segment of the Mid-Atlantic Ridge. Nature 335, 428-31.

Chen H., Sun S., HsÜ K. J., Dobson J. \& Yu Z. 1992. Tectonics of the Hainan orogenic belt: A preliminary study. Memoir of Lithosphere Tectonic Evolution Research 1, 43-8.

Chen B. \& XIE G. 1994. Evolution of the Tethys in Yunnan and Tibet. Journal of Southeast Asian Earth Sciences 9, 349-54.

ChUnG S. L., Lo C. H., LAN C. Y. et al. 1999. Collision between the Indochina and South China blocks in the early Triassic: Implications for the Indosinian orogeny and closure of eastern Paleo-Tethys. Eos Transactions of the American Geophysical Union 80, F1043.

Colwell J. B., Symonds P. A. \& Crawford A. J. 1994. The nature of the Wallaby (Cuvier) Plateau and other igneous provinces of the west Australian margin. AGSO Journal of Australian Geology and Geophysics 15, 137-56.

CRAWFORD A. J. \& VON RAD U. 1994. The petrology, geochemistry and implications of basalts dredged from the Rowley Terrace-Scott Plateau and Exmouth Plateau margins, northwestern Australia. AGSO Journal of Australian Geology and Geophysics 15, 43-54.

Dickey John S. JR, Frey F. A., Hart S. R., Watson E. B. \& THOMPSON G. 1977. Geochemistry and petrology of dredged basalts from the Bouvet triple junction, South Atlantic. Geochimica et Cosmochimica Acta 41, 1105-18.

DieTrich V. J., EMmERMANN R., OBERHÄNSLI R. \& PuCheLT H. 1978. Geochemistry of basaltic and gab- broic rocks from the west mariana basin and the mariana trench. Earth and Planetary Science Letters 39, 127-44.

ENGEL C. G. \& FisheR R. L. 1969. Lherzolite, anorthosite, gabbro, and basalt dredged from the mid-Indian Ocean ridge. Science 166, 1136-41.

ENGEL C. G. \& FisheR R. L. 1975. Granitic to ultramafic rock complexes of the Indian Ocean ridge system, western Indian Ocean. Geological Society of America Bulletin 96, 1553-78.

FAng N., Feng Q., Zhang S. \& Wang X. 1998. PaleoTethys evolution recorded in the ChangningMenglian Belt, western Yunnan, China. Comptes Rendu Academica Science Paris 326, 275-82.

FANG Z., ZHAO J.-X. \& MCCUlloCh M. T. 1992. Geochemical and $\mathrm{Nd}$ isotopic study of Palaeozoic bimodal volcanics in Hainan Island, South China: Implications for rifting tectonics and mantle reservoirs. Lithos 29, 127-39.

GuANGDONG (GUANGDONG BuREAU OF GEOLOGY and Mineral Resources). 1988. Regional Geology of Guangxi. Geological Publishing House, Beijing.

HAinAN (HAINAN GEOLOGICAL SURVEY). 1995. Geological map of Bangxi, People's Republic of China (at scale of 1:50,000). Geological Publishing House, Beijing.

HEBERT R., BIDEAU R. D. \& HEKINIAN R. 1983. Ultramafic and mafic rocks from the garret transform fault near $13^{\circ} 0^{\prime}$ on the east Pacific rise: Igneous petrology. Earth and Planetary Science Letters 65, 107-25.

HEKINIAN R. 1971. Chemical and mineralogical differences between abyssal hill basalts and ridge tholeiites in the eastern Pacific ocean. Marine Geology 11, 77-91.

Hermes O. D. \& Schilling J. G. 1976. Olivine from Reykjanes Ridge and Iceland tholeiites, and its significance to the two-mantle source model. Earth and Planetary Science Letters 28, 345-55.

Hsü K. J., Li J., Chen H., Pen H. \& Sengör A. M. C. 1990. Tectonics of South China: Key to understanding West Pacific geology. Tectonophysics 183, 9-39.

Humler E. \& WhitechurCh H. 1988. Petrology of basalts from the central Indian Ridge (lat. $25^{\circ} 23^{\prime} \mathrm{S}$, long. $70^{\circ} 04^{\prime} \mathrm{E}$ ): Estimates of frequencies and fractional volumes of magma injections in a two-layered reservoir. Earth and Planetary Science Letters 88, $169-81$.

HUTCHISON C. S. 1989. Geological Evolution of Southeast Asia. Clarendon Press, Oxford.

JAQUeS A. L. \& GREEN D. H. 1980. Anhydrous melting of peridotite at $0-15 \mathrm{~Kb}$ pressure and the genesis of tholeiitic basalts. Contribution to Mineralogy Petrology 73, 287-310.

JiAn P., WANG X., HE L. \& WANG C. 1998. U-Pb zircon dating of the Shuanggou ophiolite from Xingping County, Yunnan Province. Acta Petrologica Sinica 14, 207-11 (in Chinese with English abstract). 
Jian P., WANG X., He L. \& Wang C. 1999. U-Pb zircon dating of anorthosite and plagiogranite from the Jingshajiang ophiolite belt. Acta Petrologica Sinica 15, 590-3 (in Chinese with English abstract).

Lan C. Y., Chung S. L., Shen J. J. et al. 2000. Geochemical and Sr-Nd isotopic characteristics of granitic rocks from northern Vietnam. Journal of Asian Earth Sciences 18, 267-80.

Langmuir C. H., Bender J. F., Bence A. E., Hanson G. N. \& TAYLOR S. R. 1977. Petrogenesis of basalts from the FAMOUS area, Mid-Atlantic Ridge. Earth Planetary Science Letters 36, 133-56.

Lee C.-Y., Tsai J.-H., Ho H.-H., Yang T. F., Chung S.-L. \& CHEN C.-H. 1997. Quantative analysis in rock samples by an X-ray fluorescence spectrometer, (I) major elements. In Annual Meeting of the Geological Society of China, Abstract Volume., pp. 418-20 (in Chinese). Geological Society of China, Taipei.

Lepvrier C., Maluski H., NGUYen V. V., Roques D., AXENT V. \& RANGin C. 1997. Indosinian NWtrending shear zones within the Truong Son belt (Vietnam) ${ }^{40} \mathrm{Ar} /{ }^{39} \mathrm{Ar}$ Triassic ages and Cretaceous to Cenozoic overprints. Tectonophysics 283, 105-27.

Li X-H. 1997. Geochemistry of the Longsheng Ophiolite from the southern margin of Yangtze Craton, SE China. Geochemical Journal 31, 323-37.

LiU B., FENG Q. \& FANG N. 1991. Tectonic evolution of the Palaeo-Tethys in Changning-Menglian Belt and adjacent regions, western Yunnan. Journal of China University of Geosciences 2, 18-28.

LiU Y., LIU H. \& Li X-H. 1996. Simultaneous and precise determination of 40 trace elements in rock samples by ICP-MS. Geochimica 25, 552-8 (in Chinese with English abstract).

LUDWIG K. R. 1998. Using Isoplot/Ex: A geochronological toolkit for Microsoft Excel, Version 1.00. Berkeley Geochronology Center Special Publication no. 1.

MeiJer A. \& Reagan M. K. 1981. Petrology and geochemistry of the island of Sarigan in the Mariana arc: Calc-alkaline volcanism in an oceanic setting. Contributions to Mineralogy and Petrology 77, 337-54.

MetCALFe I. 1996. Gondwanaland dispersion, Asian accretion and evolution of eastern Tethys. Australian Journal of Earth Sciences 43, 605-23.

MetCALfe I., Shergold I. H. \& Li Z. X. 1994. IGCP 321 Gondwana dispersion and Asian accretion: Fieldwork on Hainan Island. Episodes 16, 443-7.

MiYashiro A., ShIDo F. \& EwING M. 1969. Diversity and origin of abyssal tholeiite from the Mid-Atlantic Ridge near $24^{\circ}$ and $30^{\circ} \mathrm{N}$ latitude. Contribution to Mineralogy and Petrology 23, 38-52.

Newman S., Stolper E. M. \& Stern R. J. 2000. $\mathrm{H}_{2} \mathrm{O}$ and $\mathrm{CO}_{2}$ in magmas from the mariana arc and back arc systems. Geochemistry Geophysics Geosystems 1, 1999-2027.

Nye C. J., REID M. R., AVERY V. F. \& Francis D. 1994. Geochemistry of the 1989-90 eruption of redoubt vol- cano, part I: Whole-rock major and trace element chemistry. Journal of Volcanology and Geothermal Research 62, 429-52.

Saunders A. D., Fornari D. J., Joron J.-L., TARney J. \& TREUIL M. 1982. Geochemistry of basic igneous rocks, Gulf of California. Deep Sea Drilling Project Leg 64. Initial Report of Deep Sea Drilling Project 64, 595-642.

Shido F., Miyashiro A. \& EwIng M. 1974. Compositional variation in pillow lavas from the Mid-Atlantic Ridge. Marine Geology 16, 177-90.

SHUI T. 1987. Tectonic framework of the southeastern China continental basement. Science in China, Series B 30, 414-22.

Sinton J. M., Price R. C., Johnson K. T. M., Staudigel H. \& Zindler A. 1993. Petrology and geochemistry of submarine lavas from the Lau and North Fiji backarc basins. Circum-Pacific Council for Energy and Mineral Resources Earth Science Series. In Kroenke L. W. \& Eads J. V. (eds). Basin Formation, Ridge Crest Processes and Metallogenesis in the North Fiji Basin. 15, 119-35.

Spadea P., Beccaluva L., CivetTa L. et al. 1991. Petrology of basic igneous rocks from the floor of the Sulu Sea. Proceedings of Ocean Drilling Program Science Results 124, 251-65.

Sun S.-S. \& MCDonOUGH W. F. 1989. Chemical and isotopic systematics of oceanic basalt: Implications for mantle composition and processes. In Saunders A. D. \& Norry M. J. (eds). Magmatism in the Ocean Basins. Geological Society Special Publication 42, 528-48.

Sun S.-S., NesbitT R. W. \& Sharaskin A. Y. 1979. Geochemical characteristics of mid-ocean ridge basalt. Earth and Planetary Science Letters 44, 119-38.

Tarney J., Saunders A. D., Weaver S. D., Donnellan N. C. B. \& HENDRY G. L. 1979. Minorelement geochemistry of basalts from Leg 49, North Atlantic Ocean. Initial Report of Deep Sea Drilling Program 49, 657-91.

TAYloR S. R. \& MCLEnNAN S. M. 1985. The Continental Crust: its Composition and Evolution. Blackwell Science, Oxford.

Vervoort J. D., Patchett P. J., Gehrels G. E. \& NUTMAN A. P. 1996. Constraints on early Earth differentiation from hafnium and neodymium isotopes. Nature 379, 624-7.

Weaver B. L., Tarney J. \& Saunders A. D. 1985. Geochemistry and mineralogy of basalts recovered from the Central North Atlantic. Initial Report of Deep Sea Drilling Program 82, 395-419.

Winchester J. A. \& FloYd P. A. 1976. Geochemical magma type discrimination: Application to altered and metamorphosed igneous rocks. Earth and Planetary Science Letters 28, 459-69.

Wood D. A., Varet J., Bougault H. et al. 1978. The petrology, geochemistry and mineralogy of North 
Atlantic basalts: A discussion based on IPOD leg 49 . Initial Report of Deep Sea Drilling Program 49, 597-655.

WOODHEAD J. D. 1988. The origin of geochemical variation in Mariana lavas: A general model for petrogenesis in intra-oceanic arcs. Journal of Petrology 29, 805-80.

Wu H., Boulter C. A., Ke B., Stow D. A. V. \& Wang Z. 1995. The Changning-Menglian suture zone: A segment of the major Cathaysian-Gondwana divide in Southeast Asia. Tectonophysics 242, 267-80.

XiA B., SHI K., FANG Z. \& YU J. 1991. The late Paleozoic rifting in Hainan Island, China. Acta Geologica Sinica 65, 103-15 (in Chinese with English abstract).

YANG S., YU Z., GUo L. \& SHI Y. 1989. The division and palaeomagnetism of the Hainan Island and plate tectonic significance. Journal of Nanjing University (Earth Science Edition) 1, 38-46 (in Chinese with English abstract).

Zhang Q., Li D. \& Zhang K. 1985. Preliminary study on Tongchangjia ophiolite melange from Yun County, Yunnan Province. Acta Petrologica Sinica 1, 1-14 (in Chinese with English abstract).

Zhang R., Ma G., JiAng D. et al. 1990. Precambrian Geology of Hainan Island, South China. China University of Geosciences Press, Beijing.

Zhang Q., ZhoU D. J., ZhaO D. S. et al. 1994. Ophiolites of the Hengduan Mountains China: Characteristics and tectonic settings. Journal of Southeast Asian Earth Sciences 9, 335-44. 